\title{
Rancang Bangun Water-Oil Separator Tipe Horizontal Dua Fasa Menggunakan Variasi Minyak Goreng, Pertamina Dex Dan Oli Mesin
}

\author{
Edi Tri Astuti ${ }^{1}$ a) ${ }^{2}$ Jones Aritonang ${ }^{1}$, Perdamean Sebayang ${ }^{2}$, dan Silviana \\ Simbolon ${ }^{1}$ \\ ${ }^{1}$ Program Studi Teknik Mesin, Universitas Pamulang, Jl. Surya Kencana No.1, Pamulang 15417, Tangerang \\ Selatan, Indonesia \\ ${ }^{2}$ Pusat Penelitian Fisika, Badan Riset Indonesia, Serpong 15314, Tangerang Selatan, Indonesia \\ E-mail: ${ }^{\text {a) }}$ dosen01544@unpam.ac.id
}

Received : 21 September $2021 \quad$ Revision :12 Oktober $2021 \quad$ Accepted:20 November 2021

\begin{abstract}
Abstrak: Industri terus berkembang setiap tahun, dan jumlah limbah yang dihasilkan juga meningkat, yang menyebabkan seringnya tumpahan minyak dan meningkatkan jumlah air limbah berminyak yang dihasilkan oleh industri. Pencemaran minyak merupakan masalah lingkungan yang sangat penting untuk dipecahkan. Water-oil separator adalah alat yang digunakan untuk memisahkan air dan minyak, dilakukan dengan mengubah kecepatan terapung suatu benda atau partikel berdasarkan massa jenis dan ukurannya. Rancang Bangun Water-Oil separator Tipe Horizontal Dua Fasa Menggunakan Variasi Minyak Goreng, Pertamina Dex Dan Oli Mesin merupakan penelitian yang bertujuan untuk menerapkan pemisahan air-minyak pada sistem water-oil separator. Pada penelitian ini sistem Water-oil separator diuji menggunakan variasi minyak goreng, pertamina dex dan oli mesin, dimana air dan minyak dipisahkan dengan debit minyak 1,2,3 1/menit dan kondisi debit air konstan 1 l/menit. Pengujian pada fluida minyak dan air menunjukkan pengaruh terhadap efisiensi pemisahan minyak dan air, semakin tinggi debit fluida minyak maka dan air cenderung turun, nilai efisiensi pemisahan minyak dan air akan semakin naik, dimana nilai tertinggi efisiensi pemisahan minyak dan air terdapat pada debit fluida minyak 3 1/min pada kondisi debit air konstan 1 1/min dengan nilai 94,1\%, 90,8\% dan $89 \%$, sedangkan nilai terendah efisiensi pemisahan minyak dan air terdapat pada debit fluida minyak 1 1/min pada kondisi debit air konstan 1 1/min.
\end{abstract}

Kata Kunci: Rancang Bangun, Water-Oil Separator, Horizontal, dan Dua Fasa

\begin{abstract}
The industry continues to grow every year, and the amount of waste generated is also increasing, which causes frequent oil spills and increases the amount of oily wastewater generated by the industry. Oil pollution is a very important environmental problem to solve. Water-Oil Separator is a tool used to separate water and oil, done by changing the floating speed of an object or particle based on its density and size. Water-Oil Separator Design Two Phase Horizontal Type Use Variations Of Cooking Oil, Pertamina Dex and Engine Oil a study that aims to apply water-oil separation in a water-oil separator system. In this study, the Water-Oil Separator system was tested using variations of Cooking Oil, Pertamina Dex and Engine Oil, where water and oil were separated with a water flow rate of $1 \mathrm{l} / \mathrm{min}$ and oil $1 \mathrm{l} / \mathrm{min}$ (constant). Tests on oil and water fluid show the effect on the efficiency of oil and water separation, the higher the oil and water fluid discharge tends to decrease, the value of the oil and water separation efficiency will increase, where the highest value of oil and water separation efficiency is in the oil fluid discharge $3 \mathrm{l} / \mathrm{min}$ at constant water discharge conditions of $1 \mathrm{l} / \mathrm{min}$ with values of $94.1 \%, 90.8 \%$ and $89 \%$, while the lowest value of oil and water separation efficiency is found in oil fluid discharge of 1 $\mathrm{l} / \mathrm{min}$ at constant water discharge conditions $1 \mathrm{l} / \mathrm{min}$.
\end{abstract}

Keywords: Design, Water-Oil Separator, Horizontal, and Two Phase 
10 | Jones Aritonang, et. al., Rancang Bangun Water-Oil Separator ....,

\section{PENDAHULUAN}

Aliran dua fase merupakan bagian dari aliran multi fase. Campuran minyak dan air yang mengalir secara bersamaan dalam suatu penempang atau saluran, kedua fluida mendistribusikan dirinya sendiri sesuai dengan sifat fisik dan parameter operasi. Aliran dua fase ini banyak dijumpai pada bidang industri seperti reaktor nuklir, penukar panas, dan pertambangan minyak dan gas [1].

Industri terus berkembang setiap tahun, dan jumlah limbah yang dihasilkan juga meningkat, yang menyebabkan sering terjadi tumpahan minyak dan meningkatnya jumlah air limbah berminyak yang dihasilkan oleh industri. Pencemaran semacam ini sangat merugikan bagi penduduk dan dapat menimbulkan pencemaran terhadap perairan dan lautan, sehingga berdampak pada penurunan daya dukung lingkungan dan kehidupan organisme di perairan tersebut. Pemisah minyak-air sangat penting untuk pengolahan air limbah berminyak atau tumpahan minyak. Pencemaran minyak dalam air tidak hanya menyebabkan pencemaran air yang parah tetapi juga kehidupan manusia terancam dan kesehatan semua spesies mahluk hidup lainnya [2].

Limbah minyak bumi dapat menyebabkan kerusakan ekosistem laut, seperti organisme di daerah tercemar. Dalam keadaan normal, pencemaran minyak tidak dapat ditangani secara langsung sehingga menyebabkan kerusakan lingkungan yang berkelanjutan. Pencemaran semacam ini dapat berdampak buruk pada ekosistem laut. Limbah minyak bumi merupakan zat beracun yang berbahaya karena sifat, konsentrasi dan kuantitasnya akan mencemari dan membahayakan lingkungan dan kelangsungan kehidupan di bumi, termasuk manusia. Minyak adalah salah satu sumber pencemaran air, dan lautan disebabkan oleh berbagai faktor seperti eksplorasi minyak, penyulingan minyak, kebocoran pipa dan aktivitas lainnya di kapal. Oleh karena itu, pencemaran minyak ini adalah masalah lingkungan yang sangat penting untuk diselesaikan [3].

Water-Oil Separator merupakan suatu alat pemisah fluida (air dan minyak) yang tidak saling mempengaruhi satu sama lainnya karena adanya perbedaan densitas, dimana densitas air lebih besar dari pada densitas minyak sehingga saat proses pemisahan terjadi air akan berada di bagian bawah dan minyak akan berada di bagian atas. Prinsip kerja Water-Oil Separator menggunakan hukum stokes, yaitu dengan mengubah kecepatan terapungnya suatu benda atau partikel berdasarkan massa jenis dan ukurannya [4].

Fluida merupakan zat cairan atau gas, yang mampu mengalir atau berubah bentuk mengikuti tempat atau wadahnya apabila mengalami tekanan geser, Pemberian sedikit gaya saja, akan membuat fluida mengalami perubahan bentuk yang berlangsung terus-menerus selama gaya tersebut masih bekerja [5].

Viskositas Kinematik merupakan rasio perbandingan antara viskositas dinamis dengan massa jenis fluida. Satuan viskositas kinematik, Dalam SI adalah $\mathrm{m}^{2} / \mathrm{s}$ atau Stoke $(\mathrm{St})$, dimana $1 \mathrm{St}$ (Stoke) $=10^{-4} \mathrm{~m}^{2} / \mathrm{s}[6]$.

$$
v=\frac{\mu}{\rho}
$$

Dimana :

$$
\begin{array}{ll}
\boldsymbol{\mu} & : \text { Viskositas dinamik }\left(\mathrm{Ns} / \mathrm{m}^{2}\right) \\
\boldsymbol{\rho} & : \text { Viskositas massa jenis }\left(\mathrm{Kg} / \mathrm{m}^{3}\right) \\
\boldsymbol{v} & : \text { Viskositas kenematik }\left(\mathrm{m}^{2} / \mathrm{s}\right)
\end{array}
$$

Viskositas Dinamik merupakan perbandingan tegangan geser terhadap laju perubahannya. Satuan viskositas dinamik, Dalam SI adalah $\mathrm{Pa} \mathrm{s}, \mathrm{Ns} / \mathrm{m}^{2}$, atau $\mathrm{Kg} / \mathrm{ms}$, dimana $1 \mathrm{~Pa} \mathrm{~s}=1 \mathrm{Ns} / \mathrm{m}^{2}=1 \mathrm{Kg} / \mathrm{ms}[6]$.

$$
\boldsymbol{\mu}=\frac{\tau}{\frac{d u}{d y}}
$$

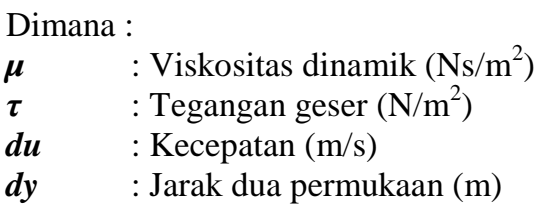

Massa Jenis merupakan ukuran kepadatan dan kerapatan jumlah molekul yang terdapat dalam satuan volume fluida [6]. 


$$
\boldsymbol{\rho}=\frac{\boldsymbol{m}}{\mathrm{V}}
$$

Dimana :

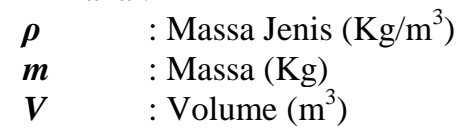

Bilangan Reynolds adalah rasio antara gaya inersia terhadap gaya viskos yang dapat menghitung dua gaya dalam kondisi aliran tertentu. Bilangan ini digunakan untuk mengetahui jenis aliran yang berbeda, seperti aliran laminar dan turbulen [7].

$$
\boldsymbol{R e}=\frac{\rho v D}{\mu}
$$

Dimana :

$\begin{array}{ll}\boldsymbol{\rho} & : \text { Massa Jenis Fluida }\left(\mathrm{kg} / \mathrm{m}^{3}\right) \\ \boldsymbol{v} & : \text { Kecepatan Aliran fluida }(\mathrm{m} / \mathrm{s}) \\ \boldsymbol{D} & : \text { Diameter Pipa }(\mathrm{m}) \\ \mu & : \text { Viskositas Dinamik }\left(\mathrm{Ns} / \mathrm{m}^{2}\right)\end{array}$

Debit aliran adalah kecepatan aliran fluida yang menenukan besar volume fluida yang melewati suatu penampang per satuan waktu. Debit aliran dinyatakan dengan [8].

$$
\begin{gathered}
\boldsymbol{Q}=\frac{\boldsymbol{V}}{\boldsymbol{t}} \ldots \ldots \ldots \ldots \ldots \ldots \ldots \ldots \ldots \ldots \ldots \ldots \ldots \ldots \ldots \ldots \\
\text { Atau: } \\
\boldsymbol{Q}=\boldsymbol{A} \boldsymbol{v}
\end{gathered}
$$

Dimana :

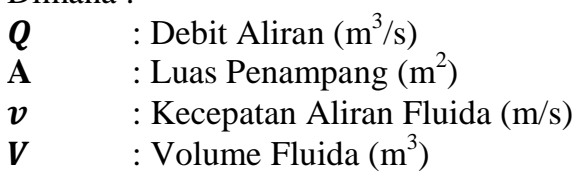

Persamaan kontinuitas merupaakan persamaan yang menghubungkan kecepatan fluida dalam dari satu tempat ke tempat lain [8].

$$
\begin{array}{r}
Q 1=Q 2 \\
A_{1} v_{1}=A_{2} v_{2} \ldots \ldots \ldots
\end{array}
$$

Dimana :

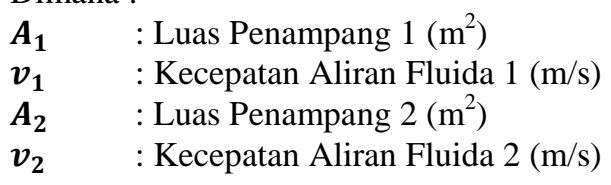

Persamaan Bernoulli merupakan kecepatan pada aliran fluida berpengaruh pada tekanan, meningkatnya kecepatan aliran fluida akan menimbulkan turunnya tekanan pada aliran fluida tersebut [8].

$$
P+\rho g h+\frac{1}{2} \rho v^{2}=\text { Konstan }
$$


Dimana :

$\begin{array}{ll}\boldsymbol{P} & : \text { Tekanan Fluida }(\mathrm{Pa}) \\ \boldsymbol{\rho} & : \text { Massa Jenis Fluida }\left(\mathrm{Kg} / \mathrm{m}^{3}\right) \\ \boldsymbol{g} & : \text { Percepatan Gravitasi }\left(\mathrm{m} / \mathrm{s}^{2}\right) \\ \boldsymbol{h} & : \text { Head / Tinggi Elevasi }(\mathrm{m}) \\ \boldsymbol{v} & : \text { Kecepatan Aliran Fluida }(\mathrm{m} / \mathrm{s})\end{array}$

Aliran laminar memiliki bilangan Reynolds yang kurang dari 2000 ( $0<\operatorname{Re}<2000)$. Aliran Laminar merupakan aliran fluida yang mengalir bergerak lurus dengan gerak partikel-partikel fluida sejajar dengan garisgaris arusnya. Aliran ini terjadi ketika kecepatan kecil dan atau viskositas besar [9].

Aliran turbulen memiliki bilangan Reynolds pada aliran turbulen lebih besar dari 4000 ( $\mathrm{Re}>4000)$. Aliran turbulen merupakan aliran fluida yang ditandai adanya aliran berputar dan arah gerak partikelnya berbeda, bahkan berlawanan dengan gerak keseluruhan fluida. Kecepatan aliran yang besar atau viskositas kecil. Pada keadaan aliran turbulen terjadi pembangkitan tegangan geser akibat dari turbulensi yang terjadi di seluruh bagian fluida sehingga terjadi penurunan tekanan pada aliran fluida yang disebut kerugian aliran [9].

Penelitian ini bertujuan untuk menerapkan pemisahan minyak dan air dan menganalisis dinamika fluida pada Water-Oil Separator Tipe Horizontal Dengan Dua Sekat.

\section{METODOLOGI}

Desain penelitian merupakan salah satu langkah yang dilakukan sebelum penelitian dilakukan agar data yang dubutuhkan utuk melakukan penelitian dapat diambil, kemudian dihitung lalu dinalisis hasil dari penelitian tersebut. Desain penelitian pada penelitian ini perlu dilakukan karena berguna sebagai panduan untuk membangun strategi yang menhasilkan model atai rancangan penelitian. Penelitian ini merupakan sebuah penelitian eksperimen dimana salah satu rangkaian pengujian dilakukan tanpa ditambahkan perlakuan apapun lalu dibandingkan dengan pengujian yang ditambahkan dengan perlakuan tertentu [10].

Table 1. Data Spesifikasi Separator

\begin{tabular}{cc}
\hline Spesifikasi & Ukuran $(\mathbf{m})$ \\
\hline Water-Oil Separator & $0,5 \times 0,2 \times 0,2$ \\
Baffle 1 & $0,2 \times 0,13$ \\
Baffle 2 & $0,2 \times 0,10$ \\
Diameter Water-Oil Mixture Inlet & 0,0127 \\
Diameter Water Outlet & 0,0127 \\
Diameter Oil Outlet & 0,0127 \\
\hline
\end{tabular}

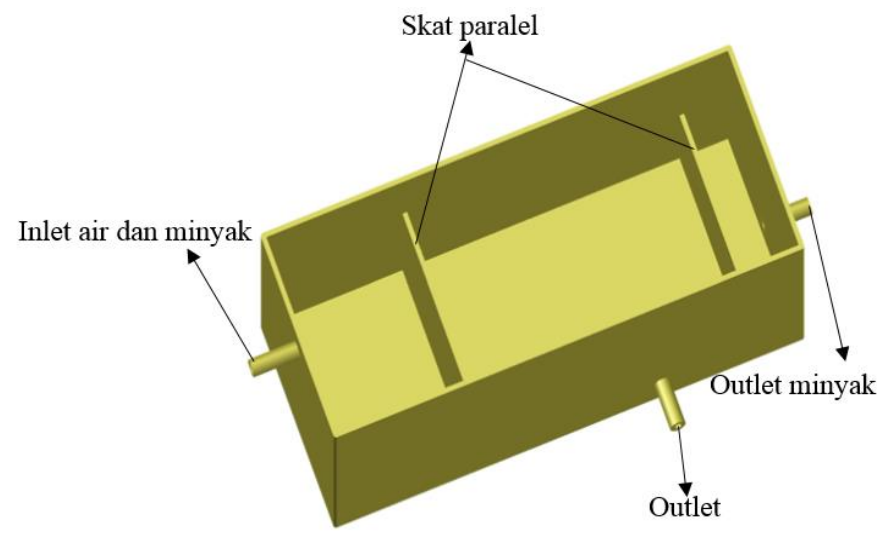

Gambar 1. Desain Separator 3 Dimensi 


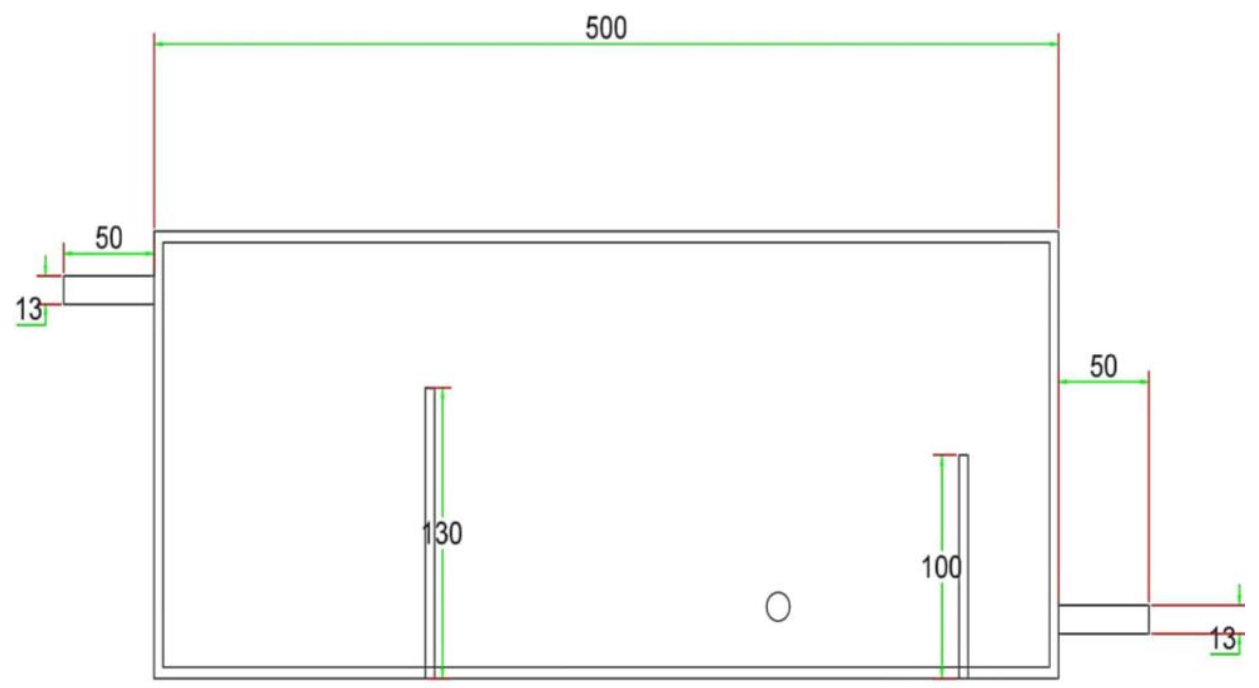

Gambar 2. Desain Separator Tampak Samping

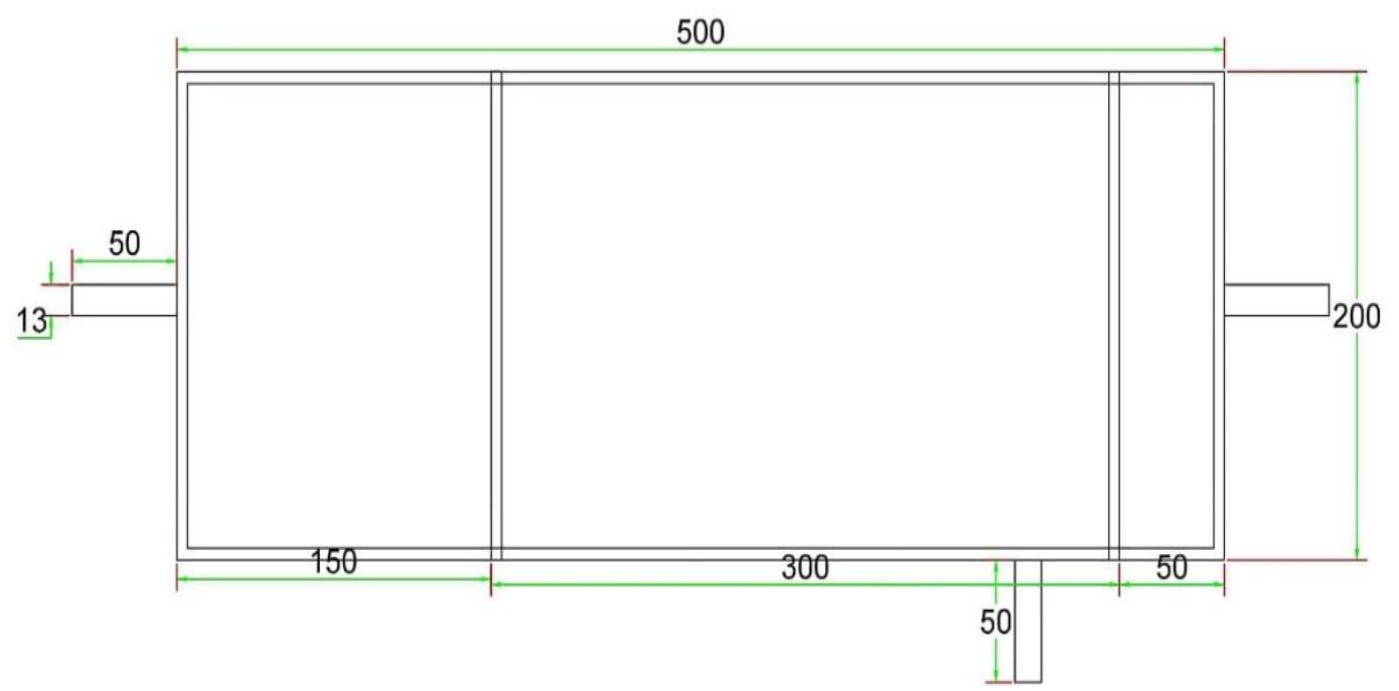

Gambar 3. Desain Separator Tampak Atas

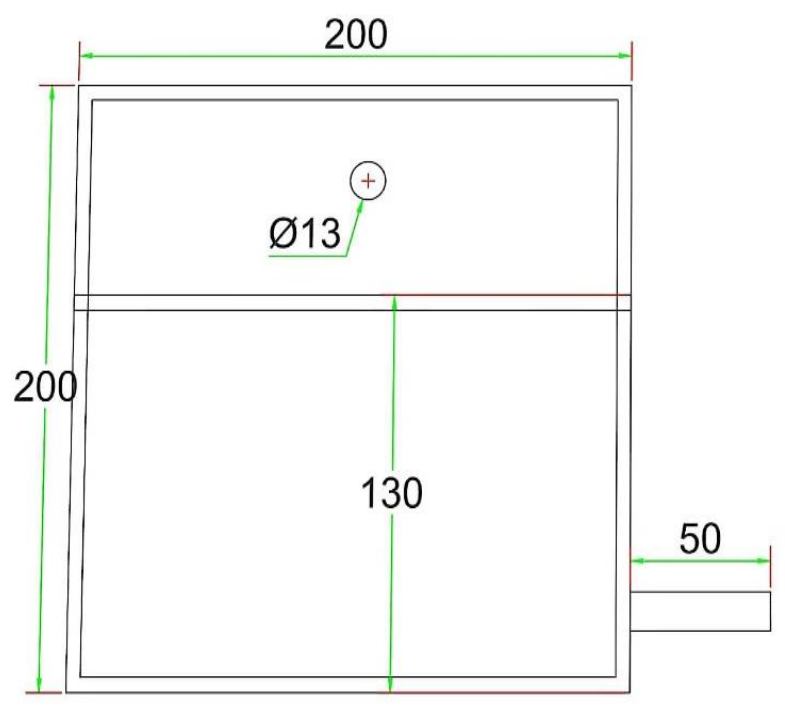

Gambar 4. Desain Separator Tampak Depan 


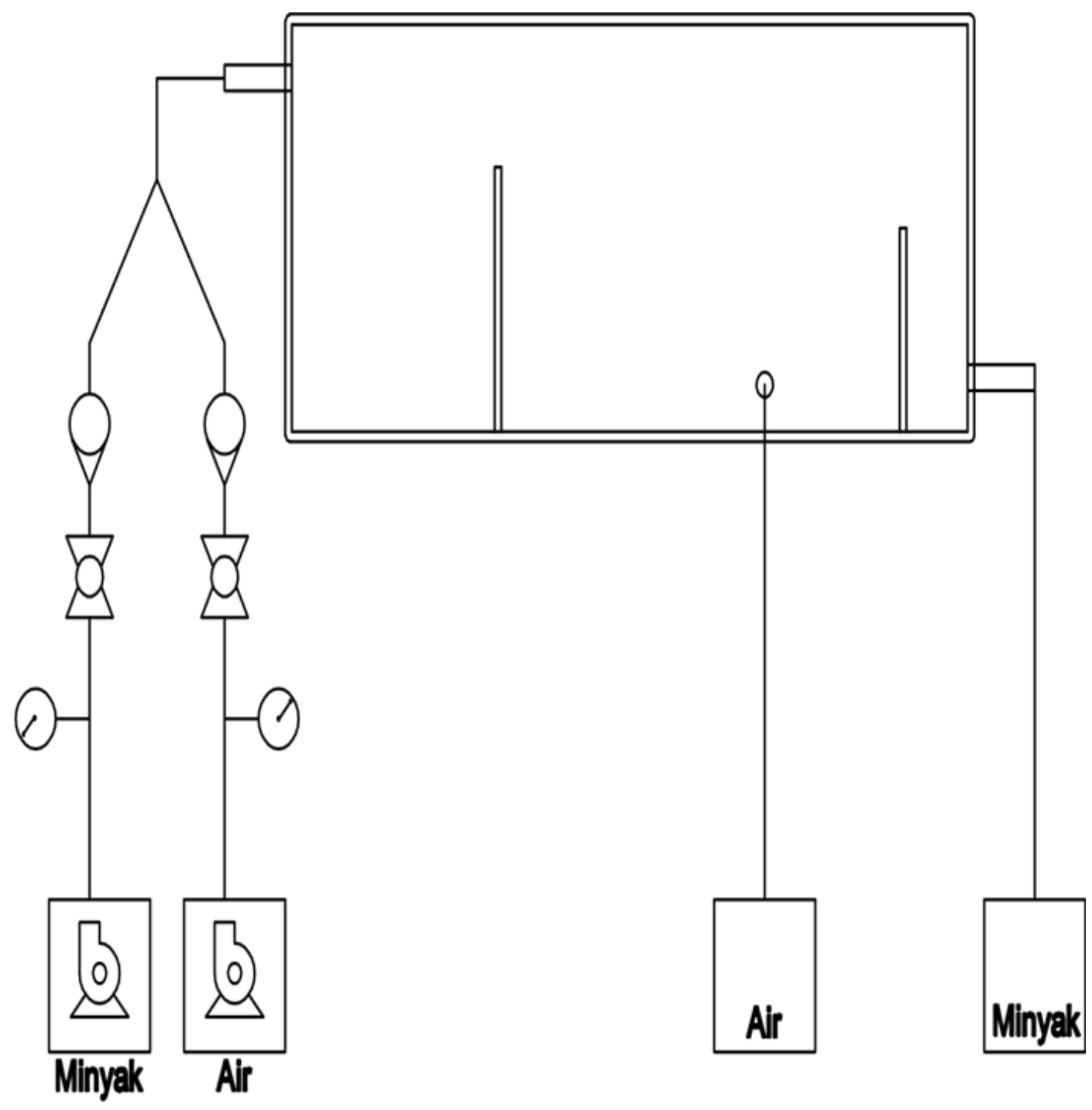

\section{Keterangan:}

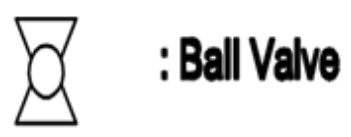

3 :Pompa

C : Pressure Gaugo

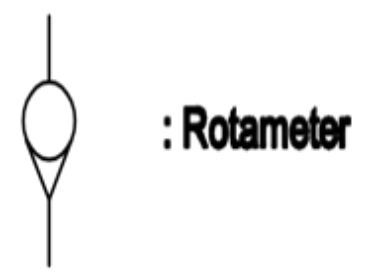

Gambar 5. Sistem Aliran Fluida 


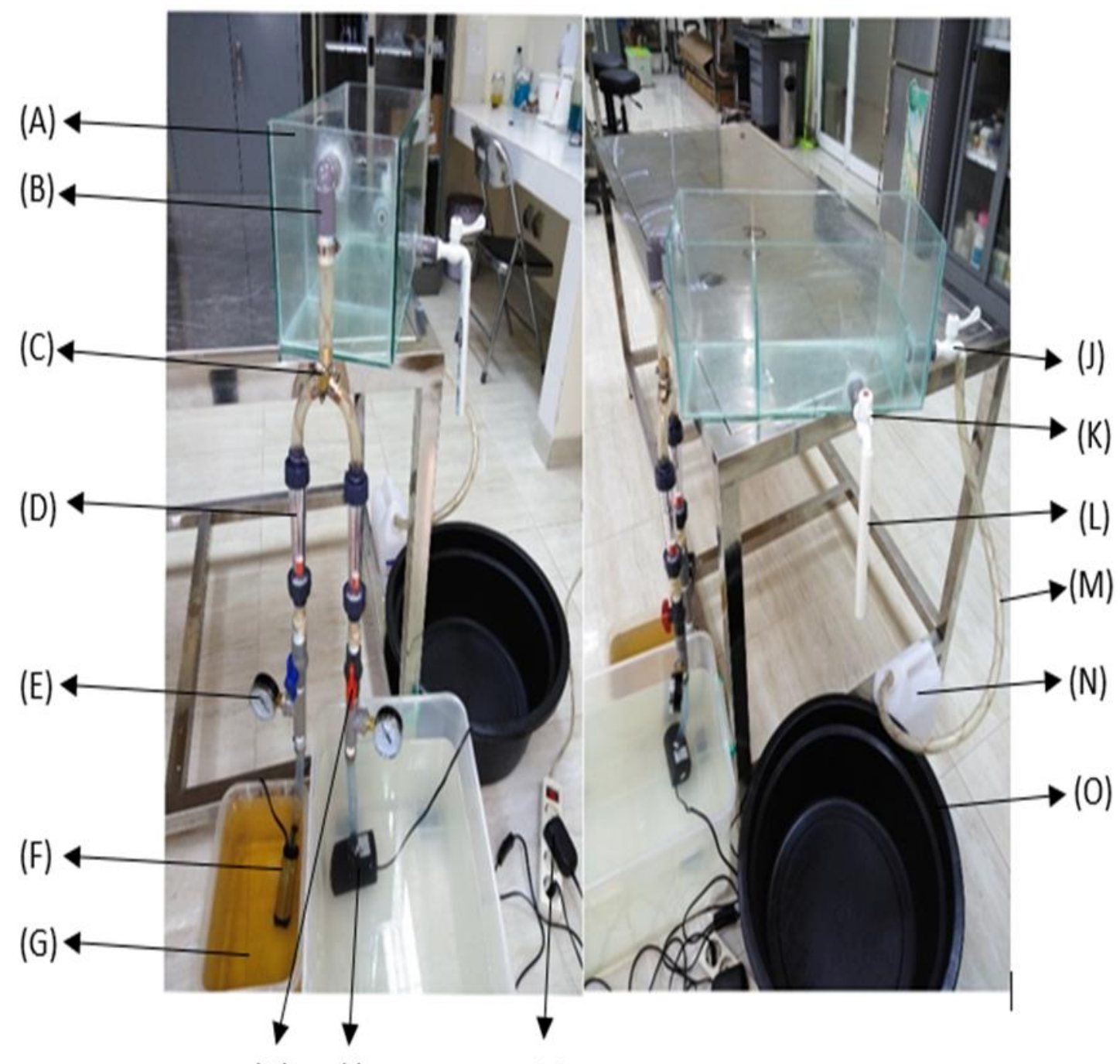

(H) (I)

(P)

Gambar 6. Alat Pengujian

Keterangan :

A. Tangki pemisah air dan minyak (Separator Tank).

B. Pipa elbow.

C. Sambungan Y.

D. Rotameter.

E. Pressure gouge.

F. Pompa minyak.

G. Tangki minyak.

H. Ball valve.

I. Pompa air.

J. Kran outlet minyak.

K. Kran outlet air.

L. Pipa outlet air.

M. Slang outlet minyak.

N. Tangki penampungan minyak.

O. Tangki penampungan air.

P. Adaptor Ac to Dc sebagai power supply pada pompa. 
16 | Jones Aritonang, et. al., Rancang Bangun Water-Oil Separator ....,

\section{HASIL DAN PEMBAHASAN}

Data yang diperoleh dari penelitian ini adalah data kuantitatif, data tersebut diolah dan dianalisis guna memperoleh kesimpulan hasil penelitian.

Table 2. Tabel Data Karakteristik Fluida Minyak Goreng Dan Air

\begin{tabular}{|c|c|c|c|c|c|c|c|c|}
\hline \multicolumn{2}{|c|}{ Debit (1/min) } & \multirow{2}{*}{$\begin{array}{c}\text { Fraksi } \\
\text { Minyak }\end{array}$} & \multicolumn{2}{|c|}{$\begin{array}{c}\text { Viskositas } \\
\text { Dinamik } \\
(\text { Pa.S }) \\
\end{array}$} & \multirow{2}{*}{$\begin{array}{l}\text { Viskositas } \\
\text { Campuran } \\
\left(\times 10^{-3} \text { Pa.S }\right)\end{array}$} & \multicolumn{2}{|c|}{$\begin{array}{c}\text { Densitas } \\
\left(\mathrm{kg} / \mathrm{m}^{3}\right)\end{array}$} & \multirow{2}{*}{$\begin{array}{c}\text { Densitas } \\
\text { Campuran } \\
\left(\mathrm{kg} / \mathrm{m}^{3}\right)\end{array}$} \\
\hline $\begin{array}{l}\text { Minyak } \\
\text { Goreng }\end{array}$ & Air & & $\begin{array}{l}\text { Minyak } \\
\text { Goreng }\end{array}$ & Air & & $\begin{array}{l}\text { Minyak } \\
\text { Goreng }\end{array}$ & Air & \\
\hline 1 & & 0,500 & & & 2,46 & & & 948,500 \\
\hline 2 & 1 & 0,666 & 0,00393 & 0,001 & 2,94 & 900 & 997 & 932,398 \\
\hline 3 & & 0,750 & & & 3,19 & & & 924,250 \\
\hline
\end{tabular}

Table 3. Tabel Data Karakteristik Fluida Oli Mesin (SAE 10)

\begin{tabular}{|c|c|c|c|c|c|c|c|c|}
\hline \multicolumn{2}{|c|}{ Debit (1/min) } & \multirow{2}{*}{$\begin{array}{c}\text { Fraksi } \\
\text { Minyak }\end{array}$} & \multicolumn{2}{|c|}{$\begin{array}{c}\text { Viskositas } \\
\text { Dinamik } \\
(\mathrm{Pa} . \mathrm{S}) \\
\end{array}$} & \multirow{2}{*}{$\begin{array}{l}\text { Viskositas } \\
\text { Campuran } \\
\left(\mathrm{x} 10^{-3} \mathrm{~Pa} . \mathrm{S}\right)\end{array}$} & \multicolumn{2}{|c|}{$\begin{array}{c}\text { Densitas } \\
\left(\mathrm{kg} / \mathrm{m}^{3}\right)\end{array}$} & \multirow{2}{*}{$\begin{array}{c}\text { Densitas } \\
\text { Campuran } \\
\left(\mathrm{kg} / \mathrm{m}^{3}\right)\end{array}$} \\
\hline $\begin{array}{c}\text { Oli } \\
\text { Mesin }\end{array}$ & Air & & $\begin{array}{c}\text { Oli } \\
\text { Mesin }\end{array}$ & Air & & $\begin{array}{c}\text { Oli } \\
\text { Mesin }\end{array}$ & Air & \\
\hline 1 & & 0,500 & & & 40,1 & & & 923,75 \\
\hline 2 & 1 & 0,666 & 0,0793 & 0,001 & 53,1 & 850,5 & 997 & 899,431 \\
\hline 3 & & 0,750 & & & 59,7 & & & 887,125 \\
\hline
\end{tabular}

Table 4. Tabel Data Karakteristik Fluida Jenis Bahan Bakar Diesel Jenis Pertamina Dex

\begin{tabular}{|c|c|c|c|c|c|c|c|c|}
\hline \multicolumn{2}{|c|}{ Debit (1/min) } & \multirow{2}{*}{$\begin{array}{c}\text { Fraksi } \\
\text { Minyak }\end{array}$} & \multicolumn{2}{|c|}{$\begin{array}{c}\text { Viskositas } \\
\text { Dinamik } \\
(\mathrm{Pa} . \mathrm{S}) \\
\end{array}$} & \multirow{2}{*}{$\begin{array}{l}\text { Viskositas } \\
\text { Campuran } \\
\left(\times 10^{-3} \text { Pa.S }\right)\end{array}$} & \multicolumn{2}{|c|}{$\begin{array}{c}\text { Densitas } \\
\left(\mathrm{kg} / \mathrm{m}^{3}\right)\end{array}$} & \multirow{2}{*}{$\begin{array}{c}\text { Densitas } \\
\text { Campuran } \\
\left(\mathrm{kg} / \mathrm{m}^{3}\right)\end{array}$} \\
\hline $\begin{array}{l}\text { Pertamina } \\
\text { Dex }\end{array}$ & Air & & $\begin{array}{l}\text { Pertamina } \\
\text { Dex }\end{array}$ & Air & & $\begin{array}{l}\text { Pertamina } \\
\text { Dex }\end{array}$ & Air & \\
\hline 1 & & 0,500 & & & 1,32 & & & 908,500 \\
\hline 2 & 1 & 0,666 & 0,00164 & 0,001 & 1,42 & 820 & 997 & 879,118 \\
\hline 3 & & 0,750 & & & 1,48 & & & 864,250 \\
\hline
\end{tabular}

Fluida kerja yang digunakan pada penelitian ini minyak goreng, oli mesin (SAE 10), dan bahan bakar diesel jenis pertamina dex dengan menghitung dan mengolah data serta mengambil kesimpulan. Pada pengujian variasi yang digunakan yaitu fluida minyak (Minyak goreng, Oli mesin (SAE10), dan Pertamina dex) dengan debit aliran pada masing-masing fluida minyak yaitu : 1,2,3 1/min dan debit air 1 1/min pada kondisi konstan. Fluida minyak yang digunakan pada penelitian ini adalah minyak goreng dengan densitas sebesar $900\left(\mathrm{~kg} / \mathrm{m}^{3}\right) \mathrm{dan}$ viskositas dinamik 0,00393 Pa.S, oli mesin (SAE 10) dengan densitas sebesar $850,5\left(\mathrm{~kg} / \mathrm{m}^{3}\right)$ dan viskositas dinamik 0,0793 Pa.S dan bahan bakar diesel jenis pertamina dex dengan densitas sebesar $820\left(\mathrm{~kg} / \mathrm{m}^{3}\right) \mathrm{dan}$ viskositas dinamik 0,00164 Pa.S. Dengan laju aliran fluida minyak dan air dipisahkan dan masing-masing dipompa melewati pressure guage, dimana debit aliran fluida minyak dan air diatur oleh ball valve dan nilai debit dicacat pada rotameter kemudian masuk kesambungan berbentuk Y, kemudian fluida minyak dan air akan naik dan bercampur mengalir ke inlet tabung separator untuk dipisahkan. 
Nilai fraksi minyak didapatkan dari hasil perhitungan data eksperimen yang telah dilakukan. Variasi debit aliran telah ditentukan oleh rotameter dan menghasilkan data kuantitatif berupa grafik hubungan antara debit fluida minyak dengan fraksi minyak dan air seperti yang ditunjukan pada Gambar 7.

Dari gambar di bawah dapat diketahui bahwa hubungan antara debit minyak 1,2,3 1/min dengan fraksi minyak pada kondisi debit air konstan 1 l/min. Nilai fraksi minyak tertinggi terdapat pada debit fluida minyak 3 1/min pada kondisi debit air konstan 1 1/min dengan nilai 0,75 , nilai fraksi minyak pada debit fluida minyak 2 1/min pada kondisi debit air konstan 1 1/min dengan nilai 0,666, sedangkan nilai fraksi minyak terendah terdapat pada debit minyak 1 1/min pada kondisi debit air konstan 1 1/min dengan nilai 0,5. Dari gambar di bawah dapat disimpulkan bahwa semakin besar debit fluida minyak yang diberikan maka semakin tinggi fraksi minyak yang masuk. Fraksi minyak akan naik seiring dengan meningkatnya debit fluida minyak, hal ini dikarenakan minyak akan lebih mendominasi pada saat masuk ke inlet separator, begitupun dengan sebaliknya fraksi minyak akan turun seiring dengan meningkatnya debit air, hal ini dikarenakan air akan lebih mendominasi pada saat masuk ke inlet separator.

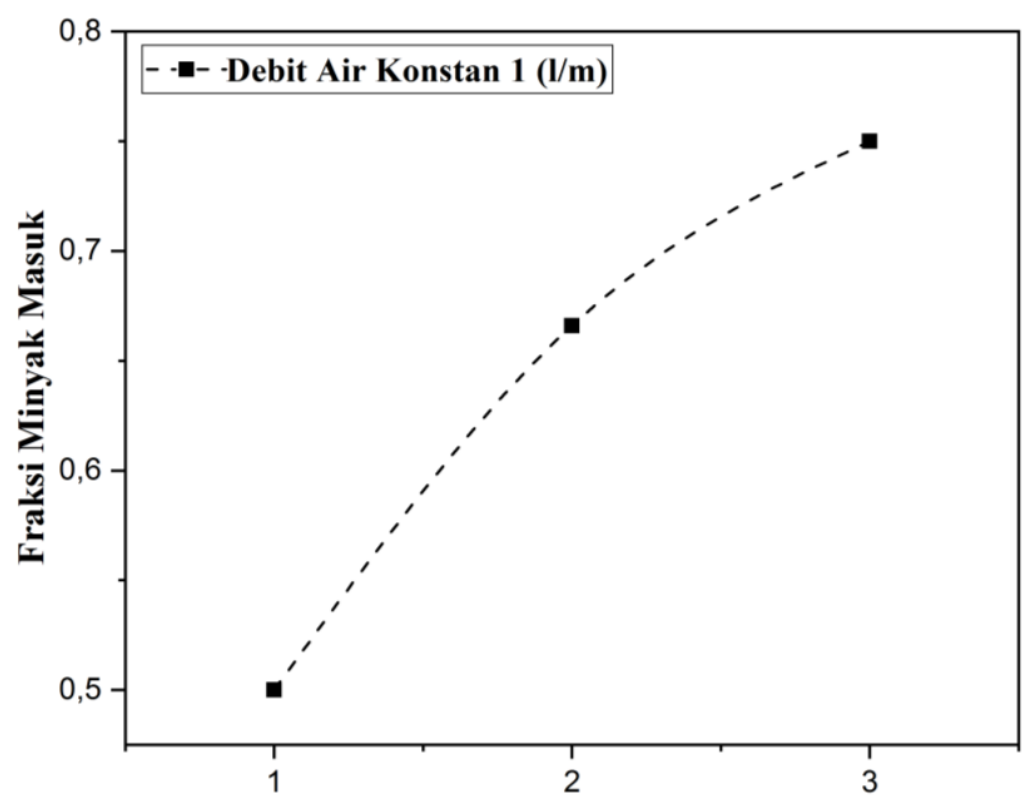

Debit Minyak Goreng, Pertamina Dex dan Oli mesin (1/m)

Gambar 7. Hubungan Antara Debit Minyak Dengan Fraksi Minyak Pada Kondisi Debit Air Konstan 1 1/min

Nilai viskositas campuran didapatkan dari hasil perhitungan data eksperimen yang telah dilakukan. Variasi debit aliran ditentukan oleh rotameter dan menghasilkan data kuantitatif berupa grafik hubungan antara debit fluida minyak dengan viskositas campuran minyak dan air seperti pada Gambar 8.

Dari Gambar grafik dibawah dengan kondisi debit fluida minyak 1,2,3 1/min pada kondisi debit air konstan 1 1/min, dapat disimpulkan bahwa semakin besar debit fluida minyak yang diberikan maka semakin tinggi viskositas campuran, berbanding terbalik debit air dengan viskositas campuran, artinya semakin besar debit air maka viskositas campuran cenderung menurun Hal ini dikarenakan viskositas campuran dipengaruhi oleh fraksi minyak, dimana semakin besar fraksi minyak maka semakin tinggi viskositas campurannya, begitu juga sebaliknya semakin kecil fraksi minyak maka viskositas campuran akan turun. Dimana fraksi minyak akan naik seiring dengan meningkatnya debit minyak, artinya minyak akan mendominasi pada saat masuk ke inlet separator, dan fraksi minyak akan turun seiring dengan meningkatnya debit air, air akan mendominasi pada saat masuk ke inlet separator. 


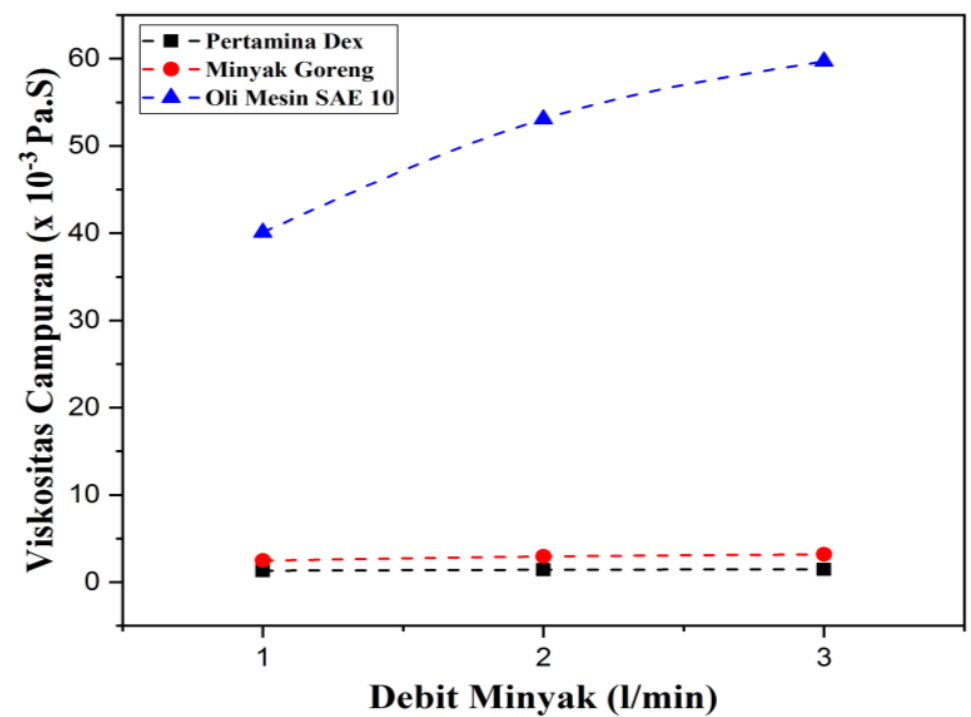

Gambar 8. Grafik Hubungan Antara Debit Minyak 1,2,3 Lpm Terhadap Viskositas Campuran Pada Kondisi Debit Air Konstan 1 1/min

Nilai densitas campuran didapatkan dari hasil perhitungan data eksperimen yang telah dilakukan. Variasi debit aliran ditentukan oleh rotameter dan menghasilkan data kuantitatif berupa grafik hubungan antara debit fluida minyak dengan densitas campuran minyak dan air seperti pada Gambar 9.

Dari Gambar grafik dibawah dapat disimpulkan dengan debit minyak (minyak goreng, oli mesin, pertamina dex) 1,2,3 1/min pada kondisi debit air konstan 1 1/min bahwa semakin besar debit minyak yang diberikan maka semakin kecil densitas campuran. Hal ini dikarenakan densitas campuran dipengaruhi oleh fraksi minyak yang masuk, pada separator, artinya semakin besar fraksi minyak masuk maka densitas campuran pada fluida akan semakin kecil. Begitupun sebaliknya dengan semakin kecil debit minyak maka densitas campuran semakin naik. Hasil grafik densitas campuran diatas mengacu pada rumus yang ada pada penelitian sebelumnya yang dilakukan oleh [11].

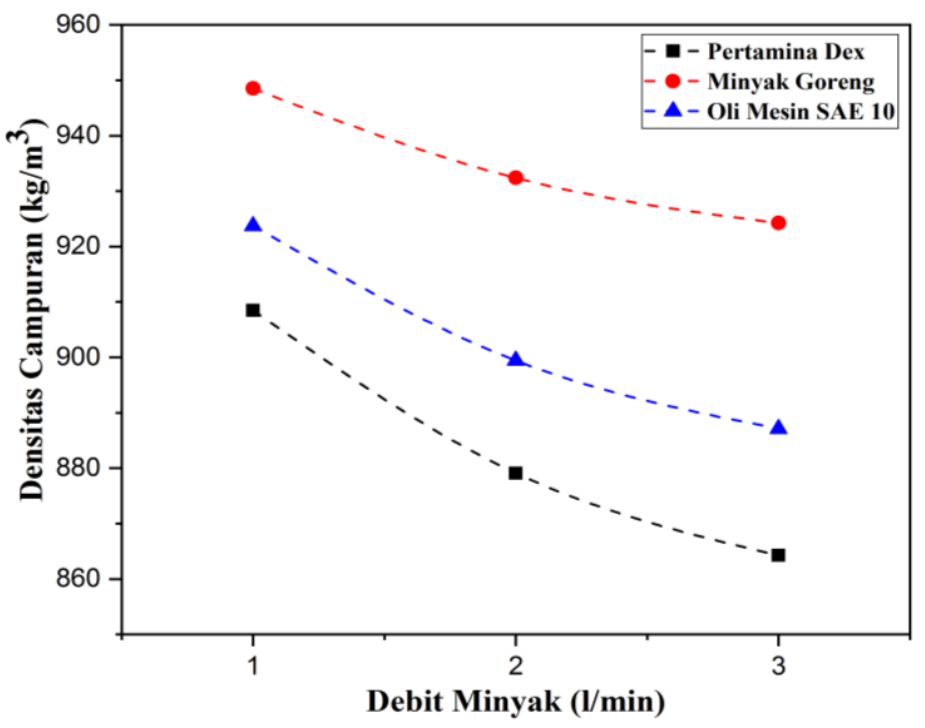

Gambar 9. Grafik Hubungan Antara Debit Minyak 1,2,3 1/min Terhadap Densitas Campuran Pada Kondisi Debit Air Konstan 1 1/min 
Nilai kecepatan aliran didapatkan dari hasil perhitungan data eksperimen yang telah dilakukan. Variasi debit aliran ditentukan oleh rotameter dan menghasilkan data kuantitatif berupa grafik hubungan antara debit fluida minyak dengan kecepatan campuran minyak dan air seperti pada Gambar 10.

Dari Gambar grafik dibawah dapat disimpulkan bahwa semakin besar debit minyak yang diberikan dengan kondisi debit air konstan 1 1/min maka semakin tinggi kecepatan campuran minyak dan air. Pernyataan tersebut sesuai dengan persamaan kontinuitas untuk menentukan debit aliran pada pipa bercabang [8].

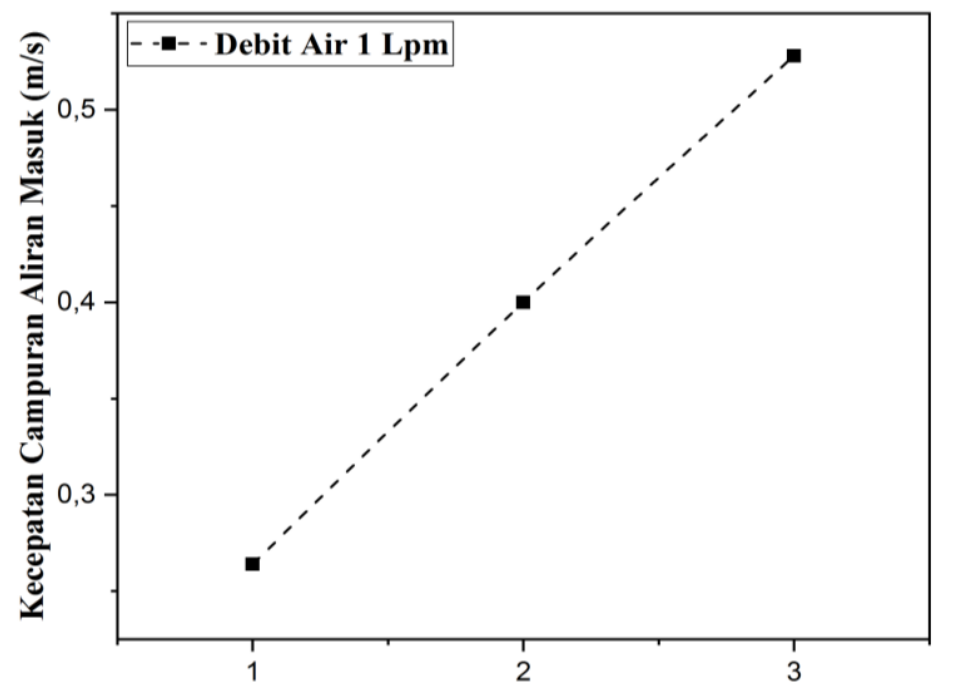

Debit Minyak Goreng, Pertamina Dex Dan Oli Mesin (1/min)

Gambar 10. Grafik Hubungan Antara Debit Minyak 1,2,3 1/min Terhadap Kecepatan Aliran Pada Kondisi Debit Air Konstan 1 1/min

Nilai reynold number didapatkan dari hasil perhitungan data eksperimen yang telah dilakukan. Variasi debit aliran ditentukan oleh rotameter dan menghasilkan data kuantitatif berupa grafik hubungan antara debit fluida minyak dengan reynold number minyak dan air seperti pada Gambar 11.

Dari Gambar dibawah disimpulkan bahwa semakin besar debit minyak yang diberikan dengan kondisi debit air konstan 1 1/min maka semakin tinggi nilai reynold number campuran. Hal ini dikarenakan debit aliran mempengaruhi kecepatan aliran, dimana semakin besar debit aliran maka kecepatan aliran semakin besar, semakin besar kecepatan aliran maka reynold number semakin besar. Reynold number juga dipengaruhi oleh viskositas, densitas, diameter pipa, artinya semakin besar viskositas maka reynold number juga semakin besar, semakin besar juga diameter pipa maka reynold number juga semakin besar bitu juga dengan densitas semakin besar densitas maka reynold number juga semakin besar. Hasil reynold number campuran pada grafik diatas mengacu pada rumus umum untuk mencari reynold number [7]. 


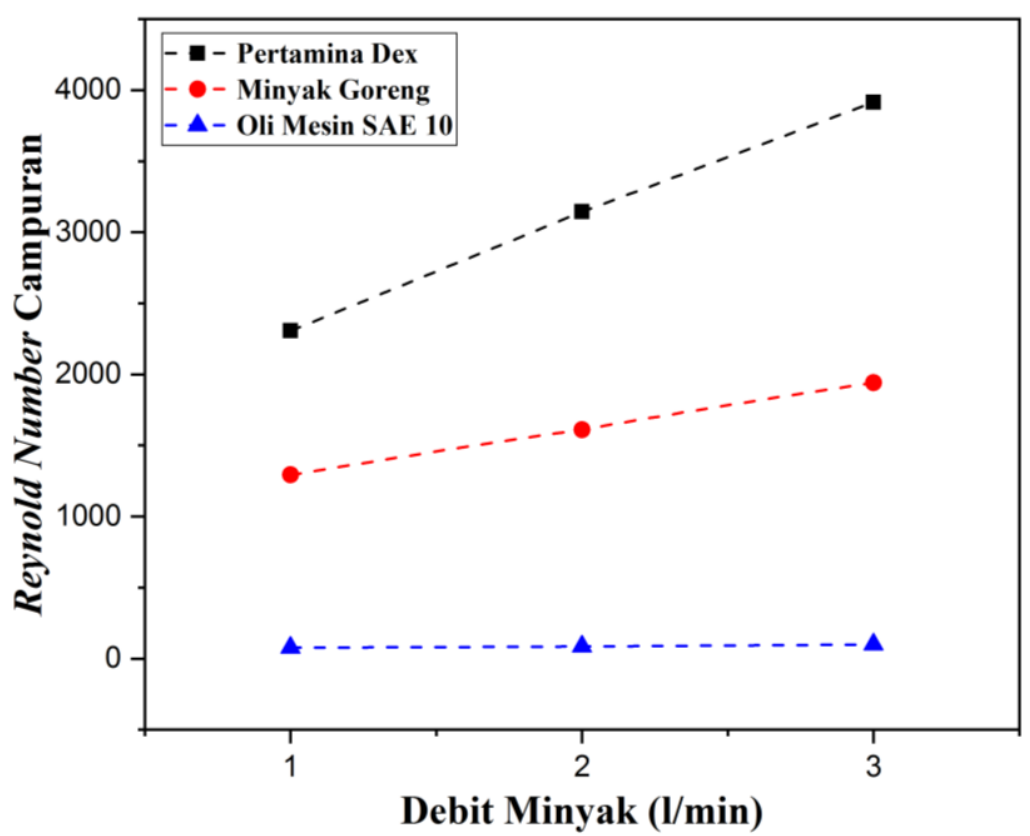

Gambar 11. Grafik Hubungan Antara Debit Minyak 1,2,3 1/min Terhadap Reynold Number Pada Kondisi Debit Air Konstan 1 1/min

Nilai efisiensi didapatkan dari hasil perhitungan data eksperimen yang telah dilakukan. Variasi debit aliran ditentukan oleh rotameter dan menghasilkan data kuantitatif berupa grafik hubungan antara debit fluida minyak dengan efisiensi pemisahan minyak dan air seperti pada Gambar 12.

Dari Gambar dibawah disimpulkan bahwa semakin besar debit minyak yang diberikan dengan kondisi debit air konstan 1 1/min maka efisiensi pemisahan minyak dan air samakin tinggi, baik itu untuk fluida minyak goreng, oli mesin dan pertamina dex. Hasil efisiensi pemisahan minyak dan air diatas mendekati penelitian yang sebelumnya dilakukan [11].

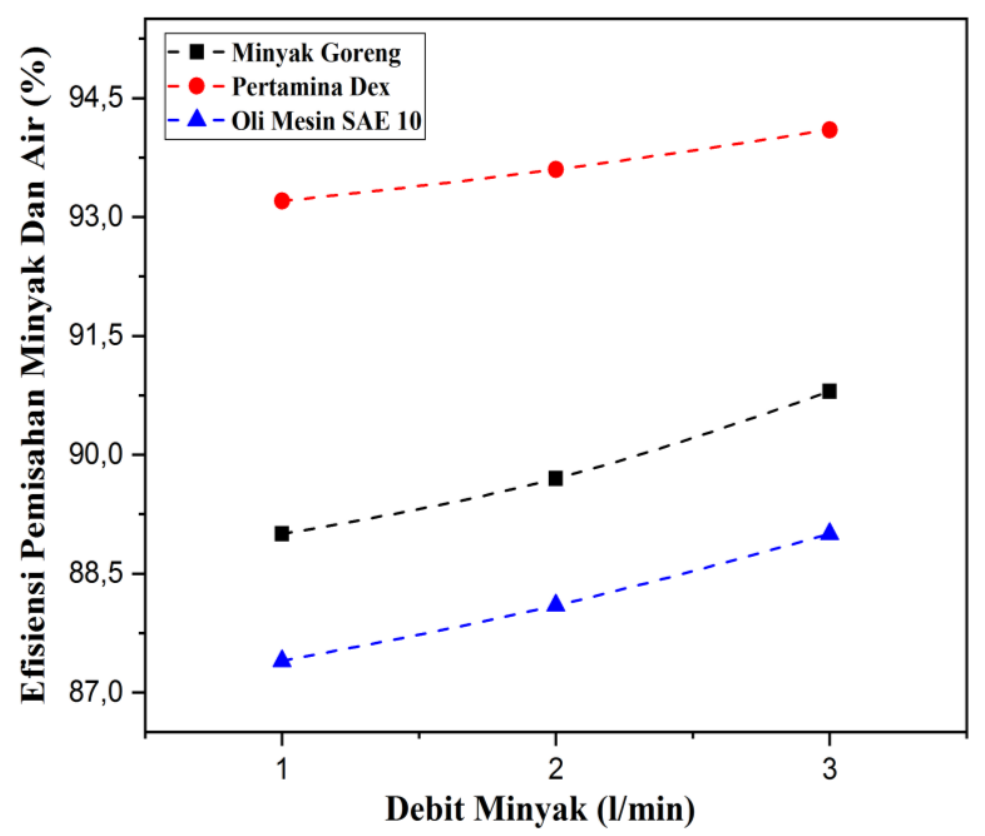

Gambar 12. Grafik Pengaruh Debit Minyak (Minyak Goreng, Pertamina Dex Dan Oli Mesin) 1,2,3 1/min Terhadap Efisiensi Pemisahan Minyak Dan Air Pada Kondisi Debit Air Konstan 1 1/min 


\section{KESIMPULAN}

Berdasarkan hasil dan analisa data dengan mengacu pada perumusan masalah, dapat disimpulkan sebagai berikut:

1. Aliran fluida minyak goreng berpengaruh terhadap pemisahan minyak dan air pada sitem water-oil separtor. Semakin besar debit aliran minyak maka fraksi minyak, viskositas campuran, kecepatan campuran, reynold number akan semakin naik, efisiensi pemisahan minyak dan air dengan nilai tertinggi 90,8\% dan nilai terendah efisensi pemisahan minyak dan air 89\%, sedangkan densitas campuran semakin turun dengan nilai tertinggi $948,5\left(\mathrm{~kg} / \mathrm{m}^{3}\right)$ dan nilai terendah densitas campuran $924,25\left(\mathrm{~kg} / \mathrm{m}^{3}\right)$.

2. Aliran fluida oli mesin (SAE 10) berpengaruh terhadap pemisahan minyak dan air pada sitem water-oil separtor. Semakin besar debit aliran minyak maka fraksi minyak, viskositas campuran, kecepatan campuran, reynold number akan semakin naik, efisiensi pemisahan minyak dan air dengan nilai tertinggi $89 \%$ dan nilai terendah efisiensi pemisahan minyak dan air 87,4\%, sedangkan densitas campuran semakin turun dengan nilai tertinggi $923,75\left(\mathrm{~kg} / \mathrm{m}^{3}\right)$ dan nilai terendah densitas campuran $887,125\left(\mathrm{~kg} / \mathrm{m}^{3}\right)$.

3. Aliran fluida pertamina dex berpengaruh terhadap pemisahan minyak dan air pada sitem water-oil separtor. Semakin besar debit aliran minyak maka fraksi minyak, viskositas campuran, kecepatan campuran, reynold number akan semakin naik, efisiensi pemisahan minyak dan air dengan nilai tertinggi 94,1\% dan nilai terendah efisiensi pemisahan minyak dan air 93,2\%, sedangkan densitas campuran semakin turun dengan nilai tertinggi $908,5\left(\mathrm{~kg} / \mathrm{m}^{3}\right)$ dan nilai terendah densitas campuran $864,25\left(\mathrm{~kg} / \mathrm{m}^{3}\right)$.

\section{UCAPAN TERIMA KASIH}

Penulis mengucapkan terima kasih kepada Program Studi Teknik Mesin-Universitas Pamulang dan Pusat Penelitian Fisika-Lembaga Ilmu Pengetahuan Indonesia atas dukungan dalam penelitian ini.

\section{DAFTAR PUSTAKA}

[1] K. Mydlarz-Gabryk, M. Pietrzak, and L. Troniewski, "Study on oil-water two-phase upflow in vertical pipes," J. Pet. Sci. Eng., vol. 117, pp. 28-36, 2014, doi: 10.1016/j.petrol.2014.03.007.

[2] M. Ge et al., "Rational design of materials interface at nanoscale towards intelligent oil-water separation," Nanoscale Horizons, vol. 3, no. 3, pp. 235-260, 2018, doi: 10.1039/c7nh00185a.

[3] E. Prayetno, T. Suhendra, and Sugianto, "Prototipe Pemisah Minyak dan Air," J. Sustain. J. Has. Penelit. dan Ind. Terap., vol. 09, no. 02, pp. 89-93, 2020.

[4] K. S. Mohr, "INTRODUCTION TO SEPARATION OF OIL AND WATER," PDHengineer.com, vol. 4023, pp. 129, 2008.

[5] D. Matos and C. Valerio, FLUID MECHANICS AND PIPE FLOW: Turbulence, Simulation and Dynamics. New York: Nova Science Publishers, Inc, 2009.

[6] W. S. Janna, Introduction to Fluid Mechanics, Fourth Edition. CRC Press, 2010

[7] F. Durst, Fluid Mechanics - An Introduction to the Theory of Fluid Flows. Springer, 2008.

[8] Ridwan, Seri Diktat Kuliah Mekanika Fluida Dasar. Penerbit Gunadarma, 1999.

[9] T. Cebeci and J. Cousteix, Modeling and Computation of Boundary-Layer FLows: Second Edition. Germany: Springer, 2005.

[10] S. Siyoto and M. A. Sodik, Dasar Metodologi Penelitian. Yogyakarta: Literasi Media Publishing, 2015.

[11] L. Piao and H. Park, "Relation between oil-water interfacial flow structure and their separation in the oil-water mixture flow in a curved channel: An experimental study," Int. J. Multiph. Flow, vol. 120, p. 103089, 2019, doi: 10.1016/j.ijmultiphaseflow.2019.103089. 